\title{
RELATIONSHIP BETWEEN POLITICS AND DAKWAH IN THE QUR'AN AND AS-SUNNAH
}

\section{HUBUNGAN POLITIK DAN DAKWAH DI AL-QUR'AN DAN AS-SUNNAH}

\author{
P-ISSN: 2085-5818 | E-ISSN: 2686-2107 \\ https://uia.e-journal.id/alrisalah/article/view/1382 \\ DOI: $10.34005 /$ alrisalah.v12i2.1382
}

Naskah Dikirim: 08-06-2021

Naskah Direview: 10-06-2021

Naskah Diterbitkan:

17-06-2021

\author{
Badrah Uyuni \\ Universitas Islam As-Syafiiyah \\ badrahuyuni.fai@uia.ac.id
}

\section{Mohammad Adnan}

Universitas Islam As Syafi'iyah

adnannur@hotmail.com

\begin{abstract}
This article discusses the concept of politics in Islam and its relation to dakwah. Whether politics and Islam are contradictory or whether politics itself is from Islam and needed in a series of dakwah. The method used in this study is the Method of Literature Study and analysis of scientific references related to relationship between politics and dakwah in the Qurán and the Sunnah's perspective. There are several verses and hadiths that are displayed in this study to understand the context. The result shows that politics is a crucial thing for a Muslim, and it is wrong if someone thinks that Islam does not have to be political justice for the entire Indonesian nation.
\end{abstract}

Keyword: Politic, Dakwah, Quran, Sunnah

\begin{abstract}
Abstrak : Artikel ini membahas tentang konsep politik dalam islam dan hubungannya dengan dakwah. Apakah politik dan Islam adalah sesuatu yang bertentangan ataupun politik sendiri merupakan bagian dari Islam dan dibutuhkan dalam rangkaian dakwah. Metode yang digunakan dalam penelitian ini adalah Metode Studi Literatur dan analisis referensi ilmiah terkait hubungan politik dan dakwah dalam perspektif Al-Qur'an dan As-Sunnah. ada beberapa ayat dan hadits yang ditampilkan dalam studi ini untuk bisa memahami konteks. Hasil studi ini menunjukkan bahwa berpolitik merupakan hal yang sangat penting bagi seorang muslim, salah jika ada orang yang beranggapan bahwa islam tidak usah berpolitik.karena pada aslinya umat islam di Indonesia harus berperan dan ikut andil dalam agenda kehidupan kebangsaan yang bersifat fundamental, seperti mewujudkan kehidupan kebangsaan yang damai, memperjuangkan keadilan bagi seluruh bangsa Indonesia.
\end{abstract}

Kata Kunci: Politik, Dakwah, Quran, Sunnah 


\section{A. Introduction}

The presumption that politics is divisive and that da'wah embraces make the majority reject and stay away from politics.

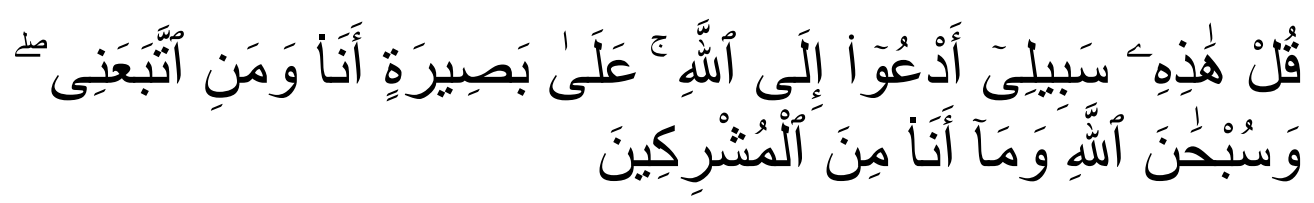

Say: "This is my way. I and those who follow me invite (you) to Allah with clear arguments. Glory be to Allah, and I am not of the idolaters." (Yusuf: 108)

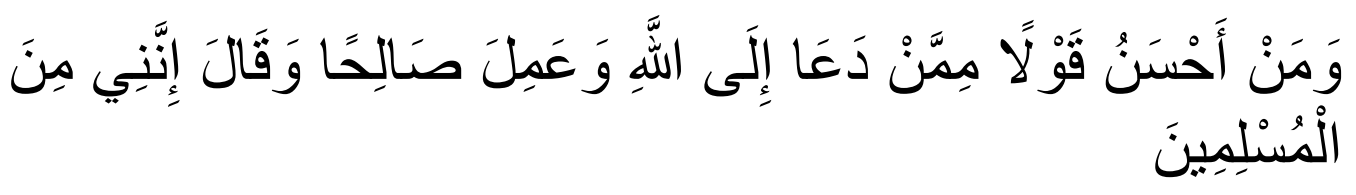

Who has a better word than he who invokes Allah, does righteous deeds, and says: "Surely I am of those who surrender?" (Fusshilat: 33)

These two verses show Muslims to call humanity to the way of Allah without coercion. Furthermore, with this, Muslims are required to preach so that others can accept the truth they receive. Because the truth of Islam is not at the theoretical level but is reflected in the form of direct activity and practice. In the task of this caliphate, da'wah becomes the essential part because human and community development only occurs if all are involved, not only individually.

Ibn Uqail, as quoted by Ibn Taymiyyah in "al Siyasah al Syar'iyyah fi Ishlah al Ra'ie wal Ra'iyyah" said that state policy is an attitude and decision that is more directed to the peace of the people and avoids damage even though the Prophet did not stipulate it. There is no Qur'anic revelation that demonstrates this policy. Ma kana filan yakunu ma'ahu al nas aqrab ila al shalah wa ab'ad ila al facade, wain lam yadha'hu al Rasul wala nazala bihi Wahyun. ${ }^{1}$

\footnotetext{
${ }^{1}$ Ibnu Taymiyyah, Al-Siyasah Al-Syar'iyyah Fi Ishlah Al-Ra'ie wal Ra'iyyah
} 
"You are the best people born for mankind, enjoining the good and forbidding the evil and believing in Allah" (Ali Imran: 110).

Allah SWT has determined that Muslims are the best of humankind. This status is given to the believers so that they become leaders and guides for other people. Sayyid Qutb in Fii Zhilalil Qur'an interprets that those who deserve to be the leaders of humanity are only "people with the best predicate." Because they want to achieve the title of the best people, the previous Muslims never stopped or were weak in their enthusiasm in the struggle to spread the message of Islam to the entire surface of the earth. They believe that the only method for realizing the revival of Islam is to make Islam a whole way of life. Islam is used as a comprehensive pattern of life. Muslims believe and believe that only Islam can solve all human affairs perfectly, thoroughly, practically, and under human nature. ${ }^{2}$

Nevertheless, at this time, Muslims are in a weak condition and situation and the lowest in understanding Islam. This condition has been proven to cause all forms of destructive thoughts to infiltrate the body of Muslims. It has resulted in the emergence of various disturbances and anxiety. Muslims tend to ignore Islamic laws quickly. Eventually, their life degenerated to a low level. In this condition, Muslims no longer have a role in international politics. There is no other way to save the people and resurrect them to a noble position, apart from returning the people to the qualities that make them the best people, namely believing in Allah SWT, carrying out commands, and preventing evil (nahi munkar), as stated in verse above.

\section{B. Research and Methods}

Research methodology is very important in guiding the researchers on proper data collection. Explanation of the methodology will ease the researcher in effecting a systematic research. This research analyses the works related to the issue of politics dakwah as a part of dakwah conducted by politician, muslim preacher, scholars and academicians. For this purpose, the research adopts the content analysis method, which focuses on the materials from the Quranic verses and prophetic tradition, and also mass media such as journals, books, written reports and other materials. This method is very suitable in analyzing the current issues and explanations of social curiosity related to the analysis.

\footnotetext{
${ }^{2}$ https://tafsirzilal.wordpress.com/2012/06/05/bahasa-indonesia-2/ accessed in 16 October 2020 at 11:07
} 


\section{Result and Discussion}

\section{The Meaning of Politics}

Politics (Greek: politikos; Arabic: سباسة, siyasah) (from Greek: politikos, meaning from, for, or relating to citizens), Politics comes from the Greek (politics - relating to the state) with the roots (polites - citizens) and (polis city-state). Etymologically the word "politics" is still related to politics, policy. And the word "politicians" means people who are engaged in politics. Politics comes from the Greek word polis, which means city or city-state. It is the process of formation and division of power in society which, among other things, is a decision -making process, in particular in the country. ${ }^{3}$ This understanding attempts to combine the various definitions of the nature of politics known in political science.

Politics is the art and science of gaining power constitutionally and unconstitutionally. In addition, politics can also be viewed from different perspectives, namely, among others: ${ }^{4}$

a. politics is an effort taken by citizens to realize the common good (Aristotle's classical theory).

b. politics is a matter related to the administration of government and the state.

c. politics is an activity directed at gaining and maintaining power in society.

d. politics is all about the process of formulating and implementing public policies.

e. In understanding politics, it is necessary to understand several keys, including political power, legitimacy, political systems, political behavior, political participation, political processes, and it is also essential to know the ins and outs of political parties.

This word was influential in the Roman territory, so that the Romans had the term ars politica, which means skill on the issue of statehood.

3 - polites means citizen.

- politicos means citizenship.

- politice tehne means political skill.

- politice episteme means political science.

${ }^{4}$ https://id.wikipedia.org/wiki/Politik accessed in 16 October 2020 at 12:07 
Politics is also known in Arabic with the word siyasah, which means to take care of one's interests. The author of al Muhith's dictionary says that sustu ar-ra'iyata siyasatan means that I command it and forbid it. While politics terminologically:

1) Refers to one aspect of human life together with society. More towards politics to gain power, enlarge or expand and maintain power (politics), for example, political crime, political activity, political rights.

2) Refers to "a set of goals to be achieved" or "certain ways or directions of activities to achieve a particular goal." More towards policy-for example, foreign politics, domestic politics, financial politics.

3) Point to the arrangement of community affairs in all aspects of life. The government regulates community affairs, and the community makes corrections to the government in carrying out its duties (siyasah).

Of the three definitions, of course, the first definition has more negative connotations than the second and third definitions. The first orientation is power politics; achieving and maintaining power can be done in any way, whether good or bad, can justify any means, and is more oriented to the interests of the leader or the ruling elite. While the second and third political definitions are more oriented to the politics of service to the community, the leader's position is a servant of the community, not the ruler of strategic assets. ${ }^{5}$

There are several basic political concepts sourced from experts, namely: ${ }^{6}$

1. Classic. In the classical view (Aristotle) argued that society uses politics to achieve a common good, which is considered to have a higher moral value than private interests. The public interest is often interpreted as moral goals or abstract ideal values such as justice, truth, and happiness. The classical view is considered blurred along with the many interpretations of the public interest itself. Public interest can also be interpreted as general will, will of all, or majority interest.

\footnotetext{
${ }^{5}$ Surbakti R, Memahami Ilmu Politik, (Jakarta: PT Grasindo, 1992)

6 Taqwa, T. (2019). DAKWAH DAN NEGARA. Vox Populi, 1(1), 64. https://doi.org/10.24252/vp.v1i1.8095
} 
2. Institutional. According to Max Weber, politics is everything related to the administration of the state. Max Weber sees the state from a fixed formal juridical point of view. The state is considered to have the right to monopolize the main physical power. However, this concept only applies to modern countries, namely countries with differentiation and specialization of roles, countries with definite territorial boundaries, and whose residents are not nomadic.

3. Power. Robson argues that politics is the activity of seeking and maintaining power or opposing the exercise of power. Power itself is a person's ability to influence others, thoughts, and actions so that they think and act according to the person who influences it. The weakness of this concept is that the concept of political and non-political aspects cannot be distinguished and that power is only one concept in political science; there are still concepts of ideology, legitimacy, and conflict.

4. Functionalism. David Easton argues that politics is the authoritative allocation of values based on the authority and binding a society. Meanwhile, according to Harold Lasswell, politics is who gets, what gets, when gets, and how gets value. It can be seen that politics is the formulation and implementation of public policies. The weakness of this concept is that the government is placed as a means and arbiter of competition between various political forces to get the most values from public policies without paying attention to the government's interests.

5. Conflict. The conflict view describes that politics is an activity to influence the formulation and general policy to influence, obtain and maintain values. Therefore, there are often debates and conflicts between those who fight for and those who defend values. The weakness of this concept is that not all conflicts have a political dimension.

In Islam, all the joints of life have been regulated primarily in politics or commonly referred to as siyasah. In political terminology, it means organizing, improving, and educating; this word is closely related to the State and power. The extent to which Islam can play a role in political struggles depends on how Muslims can come up with new styles that can develop a wealth of social and political knowledge.

Islam as a religion that is also embraced by most people in Indonesia and as a spiritual belief (which regulates the human relationship with his Lord) is also a political belief (which regulates the relationship between fellow human beings and himself). Therefore, Islam cannot be separated 
from the rules that govern society and the state. Islam is not a religion that deals with the worship of individual mahdloh only.

\section{The Meaning of Da'wah}

All areas of life can be used as da'wah, and all human life can be used as a means of da'wah.Politics is a significant thing for Muslims. If we understand how important it is to take care of the people's affairs to continue to run under Islamic law. Moreover, thinking/paying attention to the affairs of Muslims' law is fardlu (obligatory) as the Prophet said:

"Whoever in the morning pays attention to other than Allah, then Allah will depart from that person. And whoever in the morning does not pay attention to the interests of the Muslims then he does not belong to their group (the Muslims)".

Therefore, at all times, Muslims must always think about the affairs of the people, including ensuring that all these affairs are carried out under Islamic law. Because Muslims have been commanded to judge (in any matter) what Allah revealed to His Messenger, namely the Message of Islam brought by the Prophet Muhammad PBUH.

Da'wah comes from the word da "a, which means: calling, inviting, inviting, exhorting, and serving. ${ }^{7}$ Moreover, the word (sentence) with all its changes (descendants) in the Qur'an is repeated up to 215 times. $^{8}$ In the Qur'an, the term da'wah is expressed in the form of fi'il and masdar as many as more than a hundred words. The Qur'an uses the word da'wah to invite to goodness that is accompanied by the risks of each choice. In the Qur'an, da'wah in the sense of inviting is found as many as 46 times, 39 times in the sense of inviting to Islam and goodness, and seven times inviting to hell or evil. In addition, many verses explain the term da'wah in different contexts. ${ }^{9}$ Among the da'wah words used are: tabligh, nashihat, tarbiyah, tabsyir and tanzhir, amr ma'ruf and nahi munkar, mau'idhoh hasanah, indzhar, washiyah, tarbiyah, ta'lim and khotbah. The variety of words meaning da'wah in the Qur'an can be understood with several

\footnotetext{
7 Munawwir, A. W, Kamus Al-Munawwir Arab-Indonesia, (Surabaya: Pustaka Progressif, 1997), hal 438. Lihat juga: Atabik Ali dan Zuhdi Muhdlor, Kamus Kontemporer, hal. 896; Kamus Munjid, hal. 216.

${ }^{8}$ Yusuf, M., Zain, A., \& Fuadi, M. (2017). Identifikasi Ayat-Ayat Dakwah Dalam Al-Qur'an, Al-Idarah: Jurnal Manajemen Dan Administrasi Islam, 1(2), 167.

${ }^{9}$ M. Munir dan Wahyu Ilahi dalam A. M Ismatullah. Metode Dakwah Dalam Al-Qur'an: Studi Penafsiran Hamka terhadap QS. An-Nahl: 125, Vol. IXX, No. 2 (Lentera, 2015)
} 
meanings, including: First, that the Qur'an has a vocabulary/mufradat that is so rich that the use of words is more diverse. Second, that in the implementation of da'wah can be seen from multiple perspectives, so that it must use words that are more appropriate to the human condition faced.

\section{Quranic Verses on Politics}

One of the most fundamental ethics in the Qur'an is to uphold a sense of justice. The Qur'an indicates the form and system of government as whatever is run, be it a kingdom or a republic, the important thing is that justice must be upheld in it. Many verses emphasize the need to uphold justice.

a. Q.S Al-Maidah: 8

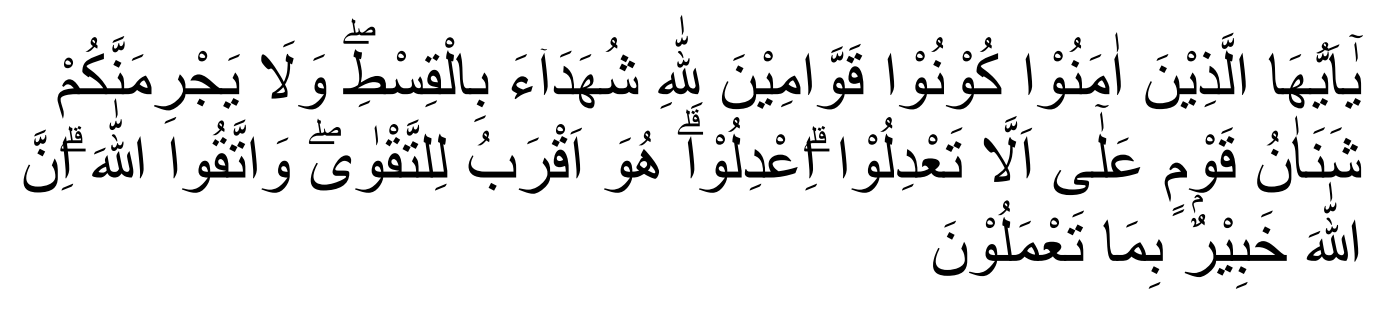

O you who believe, be the ones who always uphold (the truth) for the sake of Allah, bear witness with justice. And let not your hatred of any people cause you to act unjustly. It is fair because justice is closer to piety. And keep your duty to Allah. Lo! Allah is Aware of what ye do. (Al-Maidah/5: 8).

b. Q.S Al-Maidah: 44

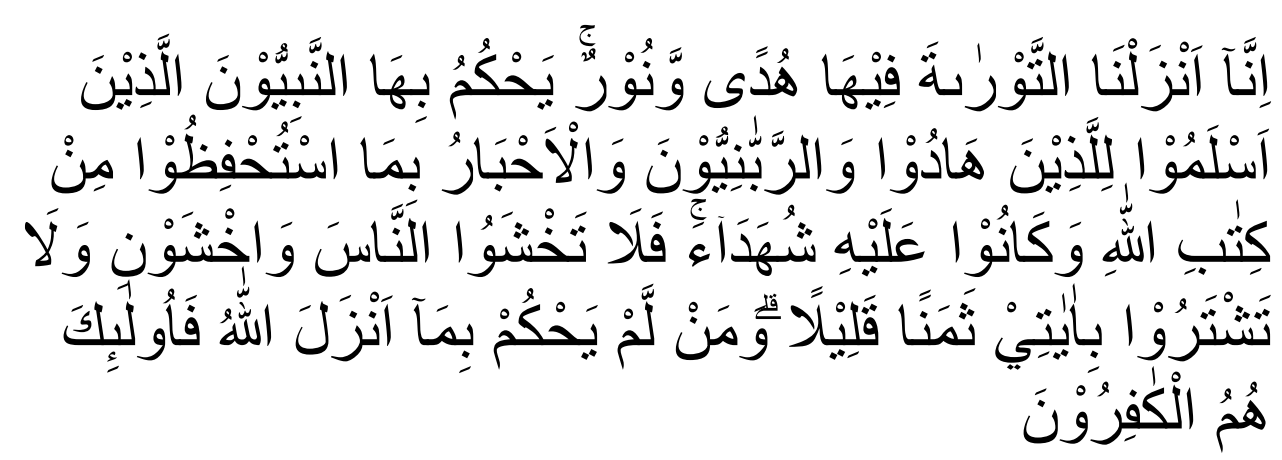

\footnotetext{
10 Yusuf, M., Zain, A., \& Fuadi, M. (2017). Identifikasi Ayat-Ayat Dakwah Dalam Al-Qur'an. Al-Idarah: Jurnal Manajemen Dan Administrasi Islam, 1(2), 167. https://doi.org/10.22373/al-idarah.v1i2.2674
} 
"... Whoever does not decide (matters) according to what Allah has sent down, then they are the disbelievers". (Al-Maidah: 44)

C. Q.S Al-Maidah: 45

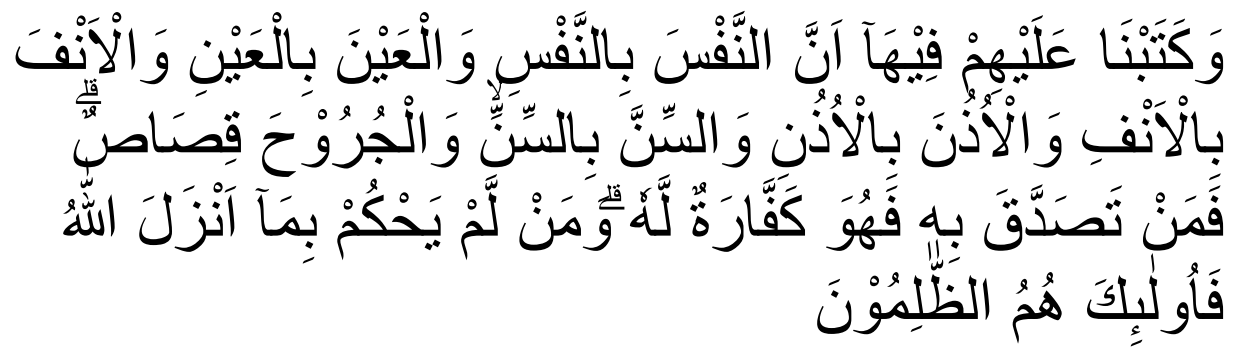

We have decreed for them in it (the Torah) that life (retribution) for life, eye for eye, nose for nose, ear for ear, tooth for tooth, and wounds (also) there is qisas (equal retribution). . Whoever relinquishes his (right of qisas), then it (becomes) an atonement for him. And whoever does not judge by what Allah has revealed, then they are the wrongdoers. (Al-Maidah: 45)

d. Q.S Al-Maidah: 47

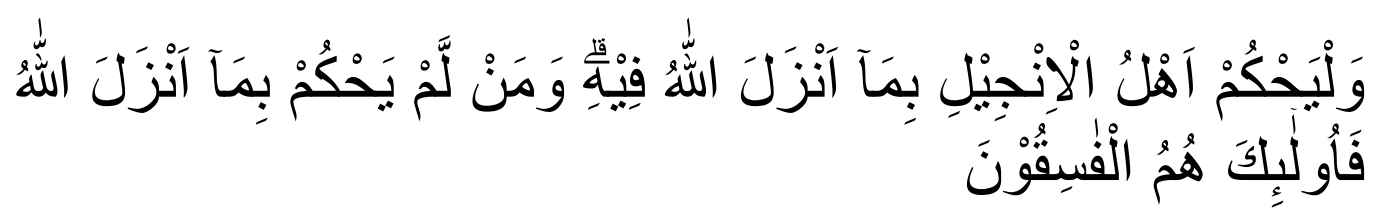

And let the followers of the Gospel decide matters according to what Allah has revealed therein. Whoever does not judge by what Allah has revealed, then those are the transgressors. (Al-Maidah: 47)

e. Q.S Al-Maidah: 48

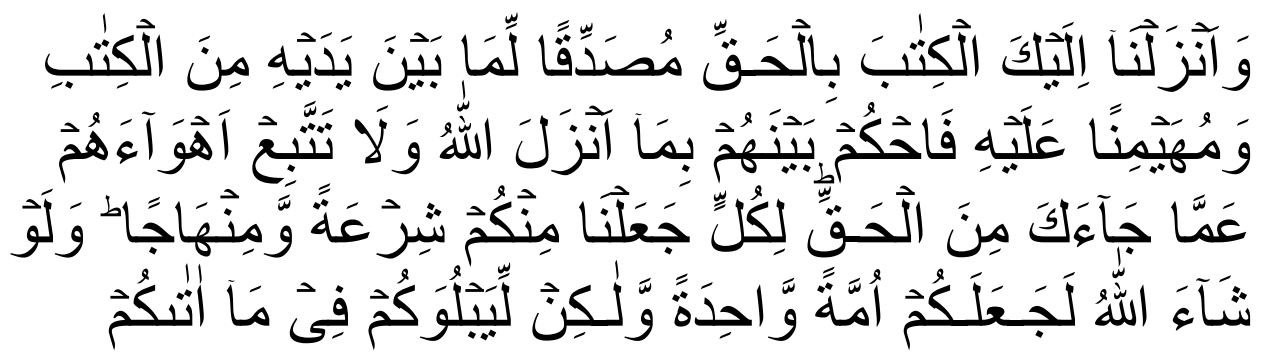

Badrah Uyuni | Relationship Between Politics And Dakwah In The Qur'an And As-Sunnah 


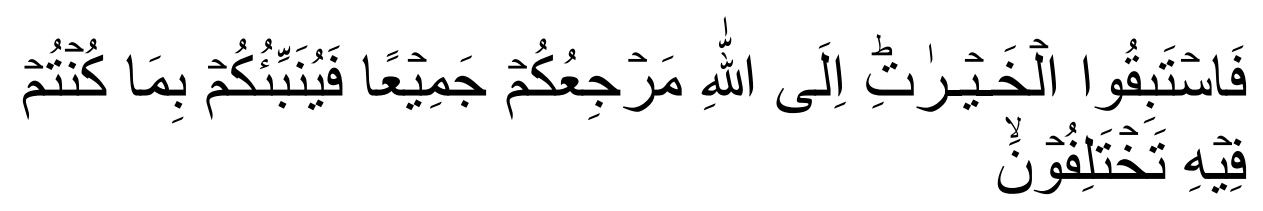

"... Then decide (matters) for them according to what Allah has sent down and do not follow their desires by leaving the truth that has come to you... .." (Al-Maidah: 48)

f. Q.S Al-Maidah: $\mathbf{4 9}$

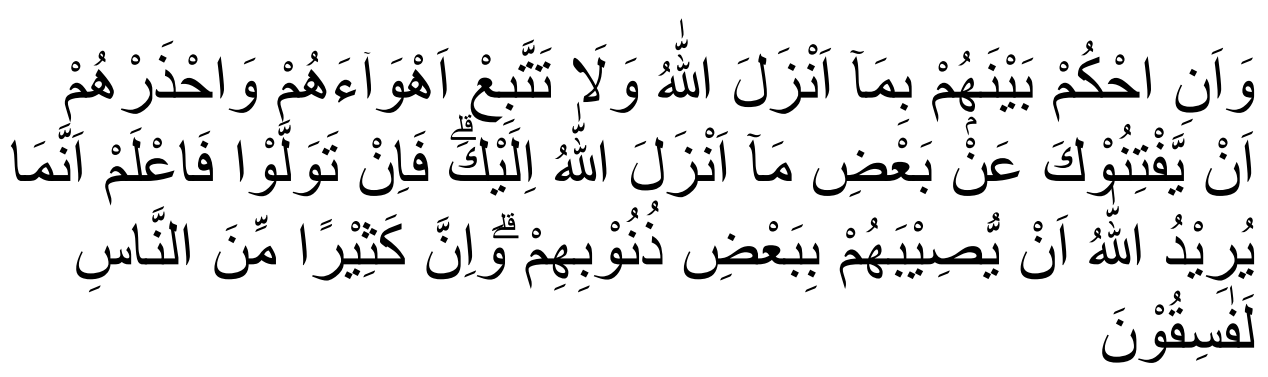

And judge between them according to that which Allah hath revealed, and follow not their desires. And beware of them lest they deceive you about some of what Allah has sent down to you. But if they turn away (from the law which Allah has sent down), then know that Allah intends to afflict them because of some of their sins. And indeed, most people are wicked people. (Al-Maidah: 49)

\section{g. Q.S An-Nisa: 65}

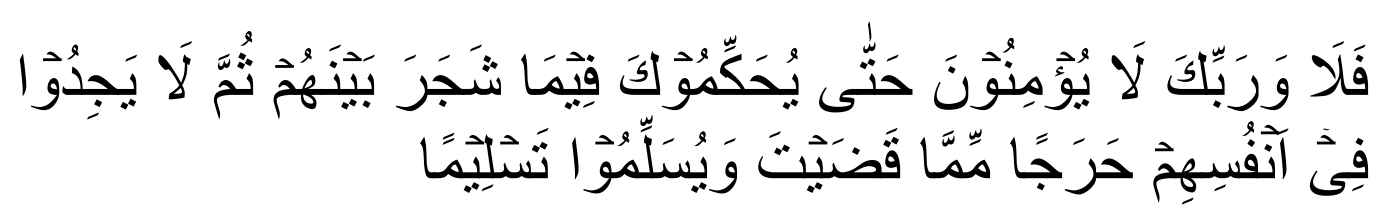

So, by thy Lord, they did not believe until they made thee a judge in their dispute, (until) then there was no remorse in their hearts against what you had given them, and they accepted it wholeheartedly. (An-Nisa: 65)

These verses explain that Muslims must (must) base all decisions on any matter to the provisions of God, namely Islamic law. The implementation of the affairs of the ummah following Islamic Shari'ah law covers domestic affairs and foreign affairs. Muslims also interact with other countries, which must always be bound by Islamic law in any implementation. And the Muslims concern on ummah means taking care of their interests and 
welfare, knowing what the rulers do to the people, denying the crimes and tyranny of the rulers, caring for the interests and problems of the people, advising tyrannical leaders, boosting the authority of rulers who violate sharia ' at Islam, as well as exposing the evil plots of enemy countries and other matters about the affairs of the ummah.

\section{Prophetic Hadits on Politics}

Prophet Muhammad SAW was admired by friends and foes because of his principles of justice. He always encouraged his friends to promote and uphold a sense of justice in society, including the non-Muslim population. A sense of fairness to all citizens, regardless of gender, race, religion, and nationality, was considered very fundamental by the Prophet. Many hadiths can be used to show how the Prophet was very concerned about the fair treatment of specific people or ethnicities, including differences in religion, sect, and belief. Every time there was a war, the Prophet always called a war not to kill innocent civilians, disturb children and widows. The Prophet also never discriminated against people based on skin color.

\section{a. The welfare of the people is the responsibility of a leader}

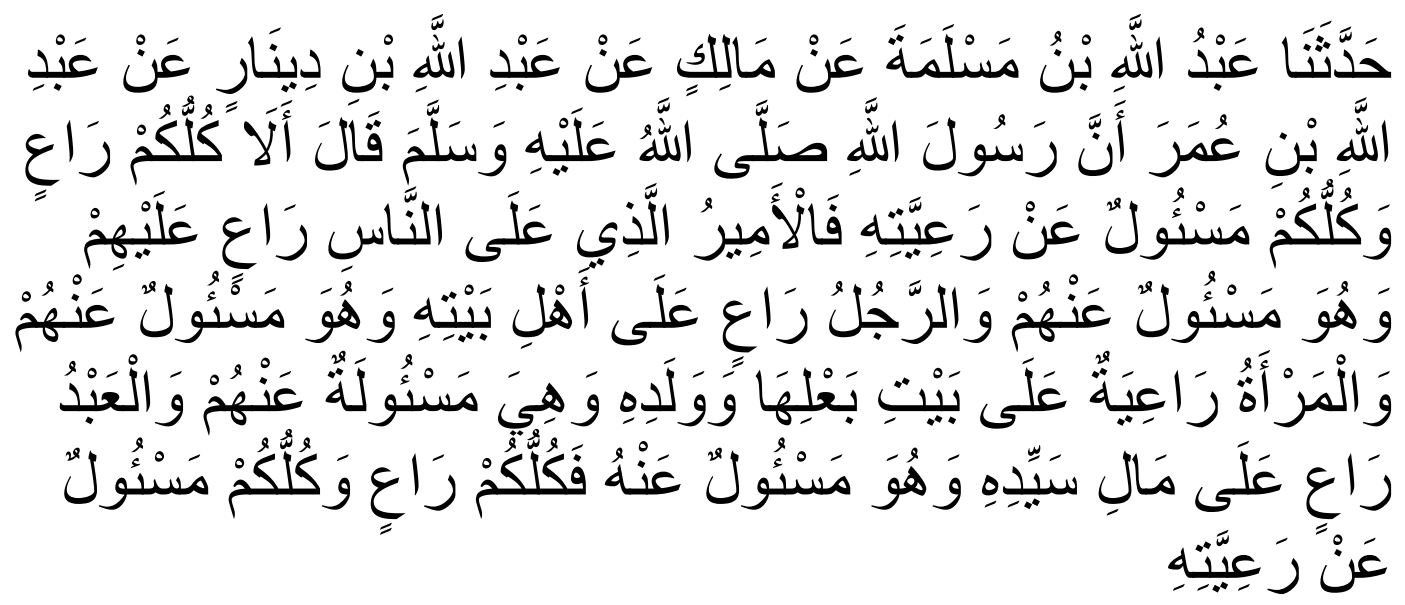

Ibn Umar r.a said: I have heard the Messenger of Allah PBUH say: everyone is a leader and will be held accountable for his leadership. Ahead of state will be held accountable for the people he leads. A husband will be asked about the family he leads. A wife who takes care of her husband's household will be asked about her responsibilities and duties. Even a maid/domestic worker in charge of maintaining her employer's belongings will also be asked about the things she leads. And 
you are leaders and will be questioned about what he led the most basic ethic in leadership is the responsibility. (HR. Bukhari Muslim)

\section{b. The punishment for leaders who deceive the people}

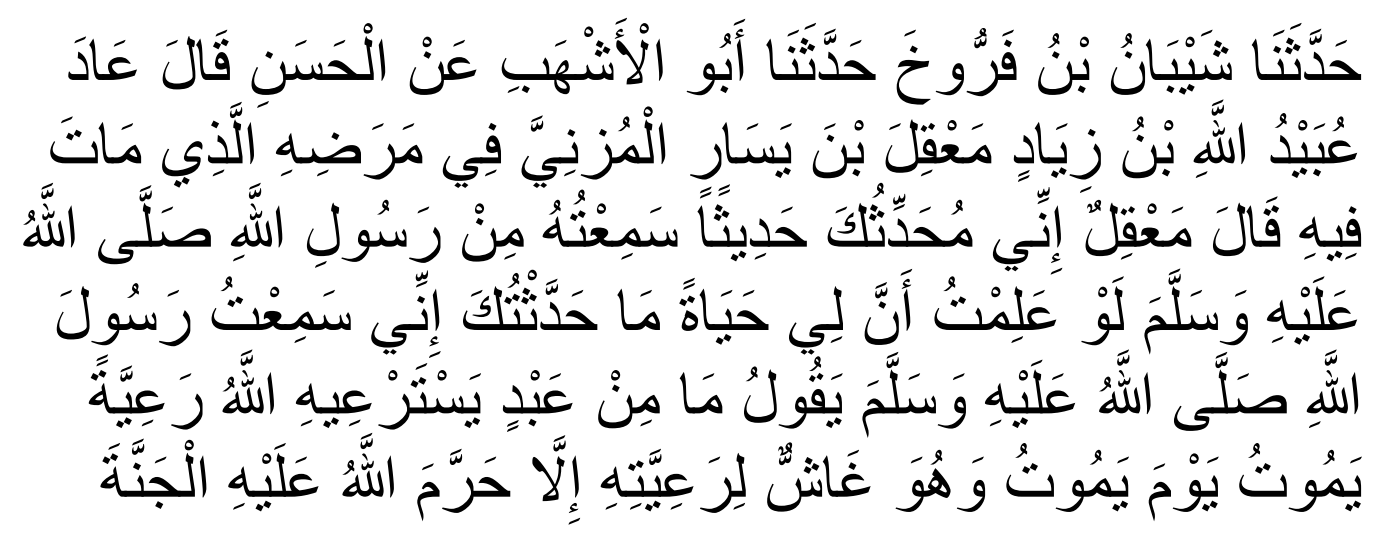

Abu ja'la (ma'qil) bin jasar r.a said: I have heard the Messenger of Allah PBUH say: no one whom Allah entrusts to lead the people then when he dies he still deceives his people unless indeed Allah forbids his paradise. Honesty is the most fundamental capital in a leadership. (HR. Bukhari Muslim)

\section{c. Leaders are servants of the people}

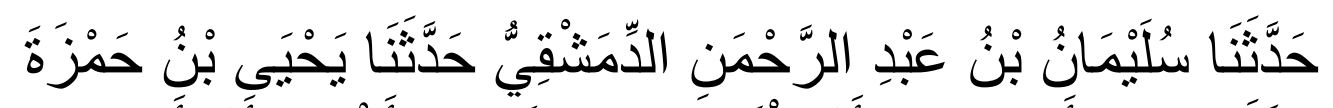

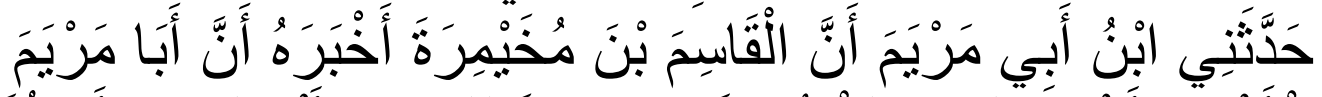

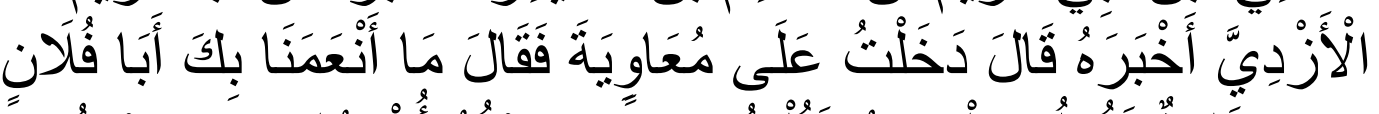

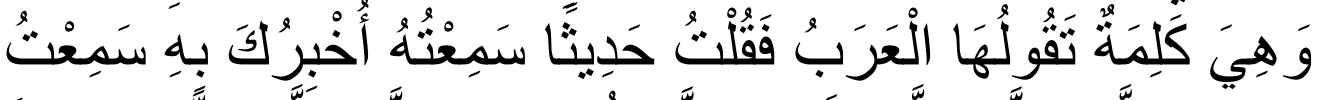

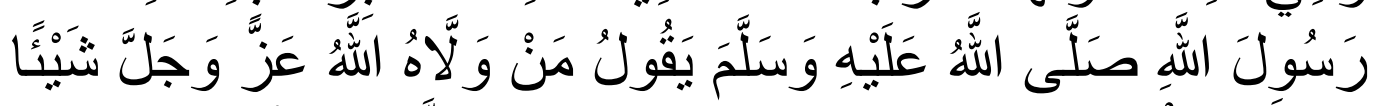

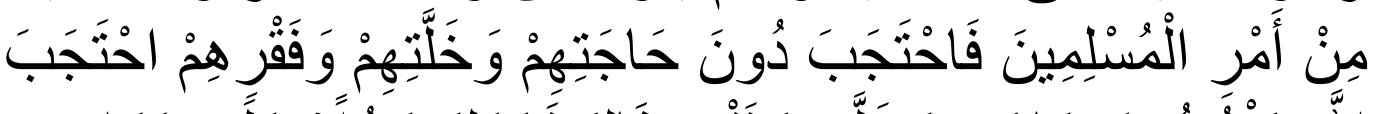

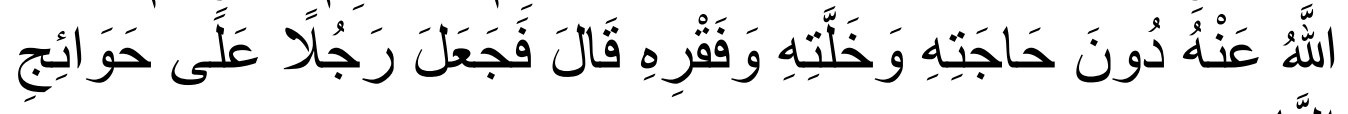

Abu Maryam al 'Azdy r.a said to Muawiyah: I have heard the Messenger of Allah PBUH say: whoever is entrusted by Allah to arrange the interests of the Muslims, which he then hides from their interests, then Allah will reject 
his interests and needs on the Day of Judgment. So then Muawiyah appointed a person to serve all the needs of the people (people). (HR. Abu Dawud and Attirmidzy)

\section{d. The limits of the people's obedience to the leader}

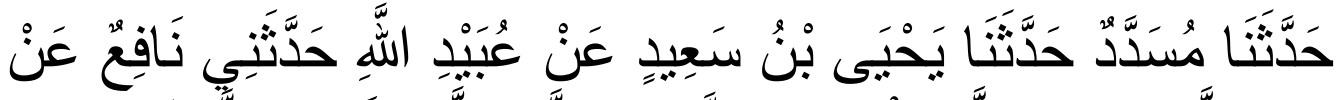

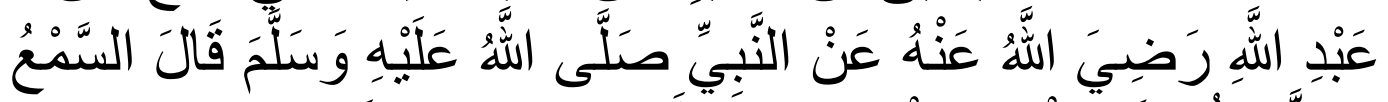

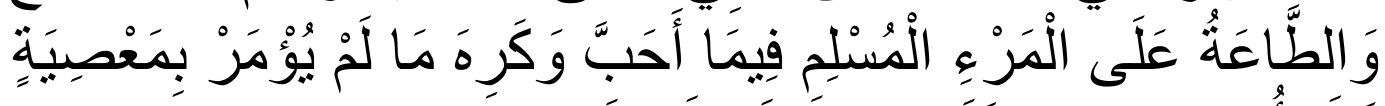

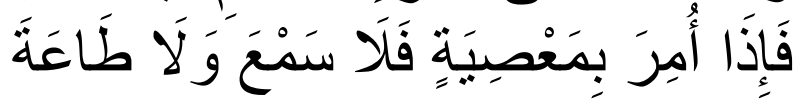

Ibn Umar r.a said: The Prophet PBUH said: A Muslim must listen to and obey his rule, in what is approved or disapproved of unless commanded by ma'siyat. So if ma'siyat is ordered, it is not obligatory to listen, and it is not obligatory to obey.

e. The balance of people's rights and the responsibilities of leaders

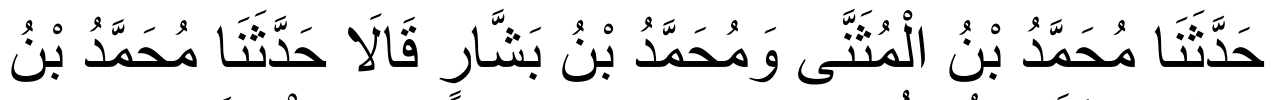

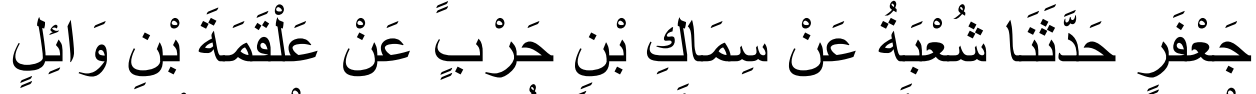

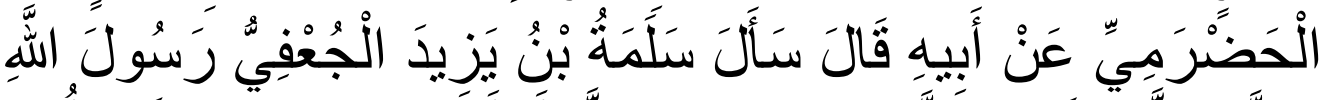

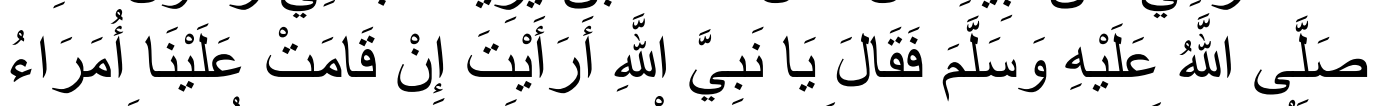

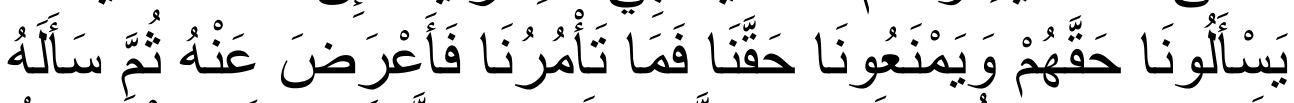

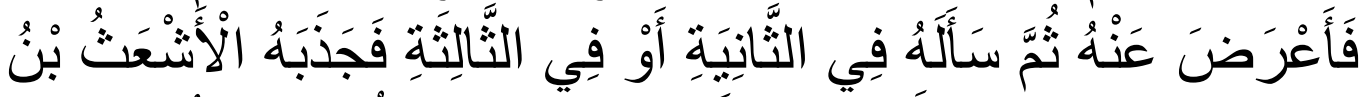

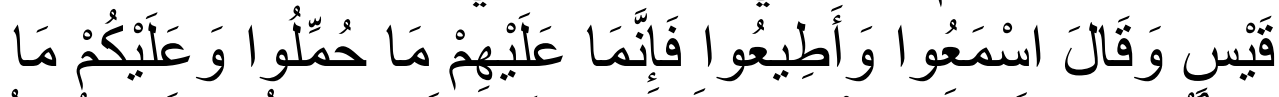

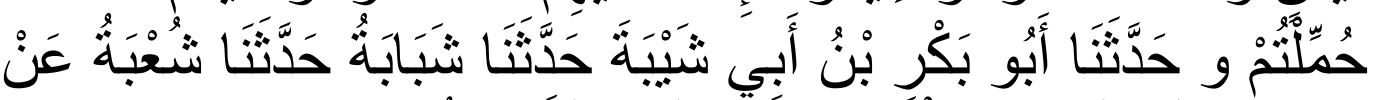

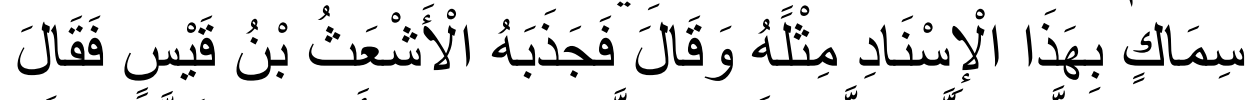

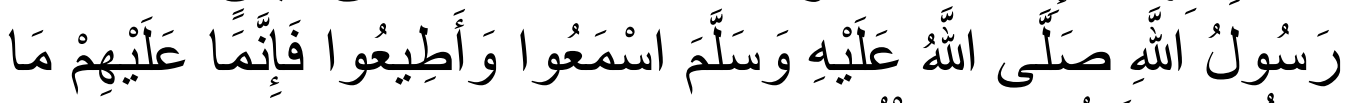

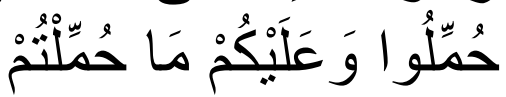


Abu hunaidah (wa'il) bin hadjur r.a. Said: Salamah bin Jazid aldju'fy asked the Messenger of Allah PBUH: O Messenger of Allah, what if the heads who are only good at claiming their rights and withholding our rights are raised above us, then how do you tell us to do? At first, the Prophet ignored the question, until he was asked a second time, then the Prophet PBUH said: listen and obey, then it is true that for each of their obligations there is a responsibility on them and you is your responsibility. (HR. Muslim)

\section{f. Leaders are prohibited from exploiting lay people.}

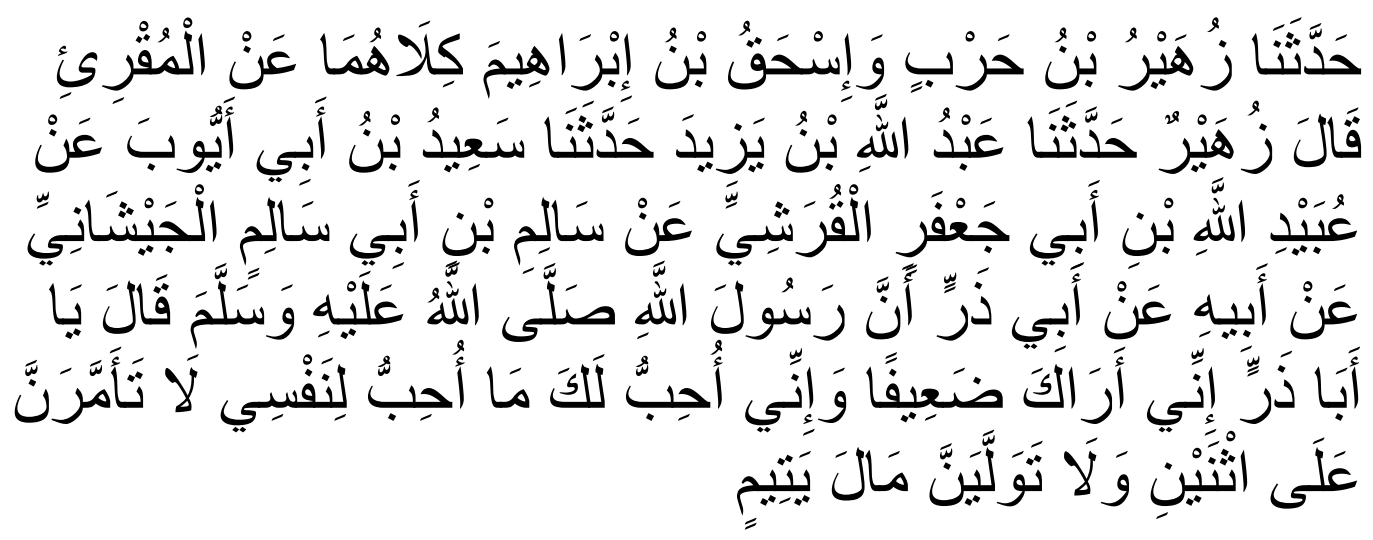

Abu dzar r.a. Said: The Messenger of Allah PBUH said: O Abu Dharr, I see you as a weak person, and I like for you what I like for myself, do not be a leader even against two people, and do not control the property of orphans.

\section{g. The Stupid Leader}

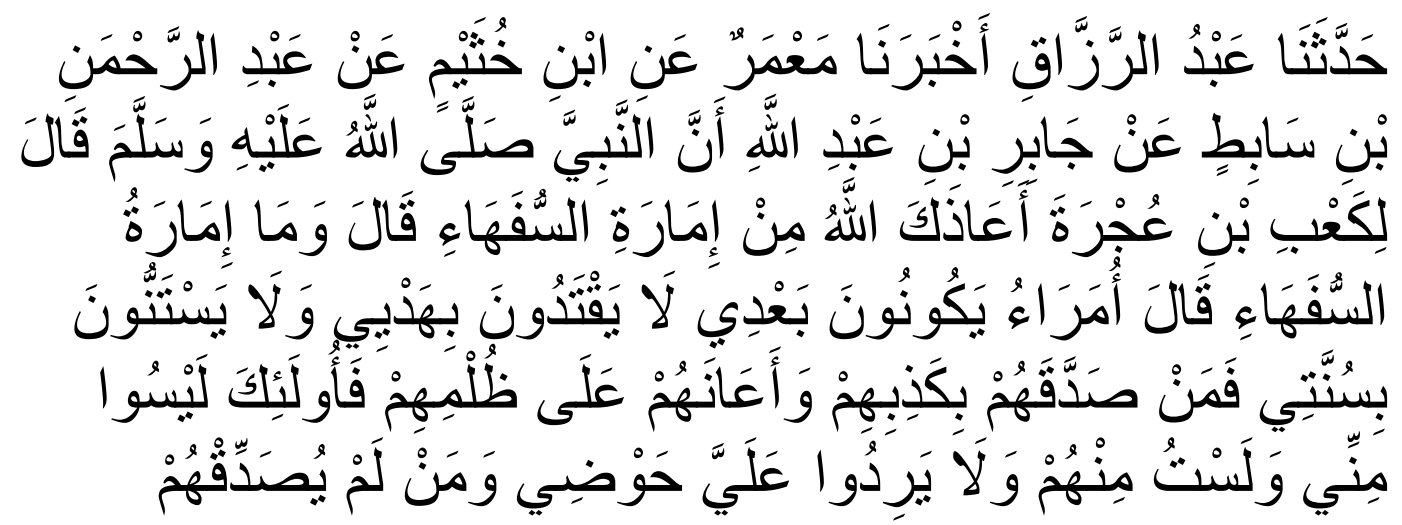




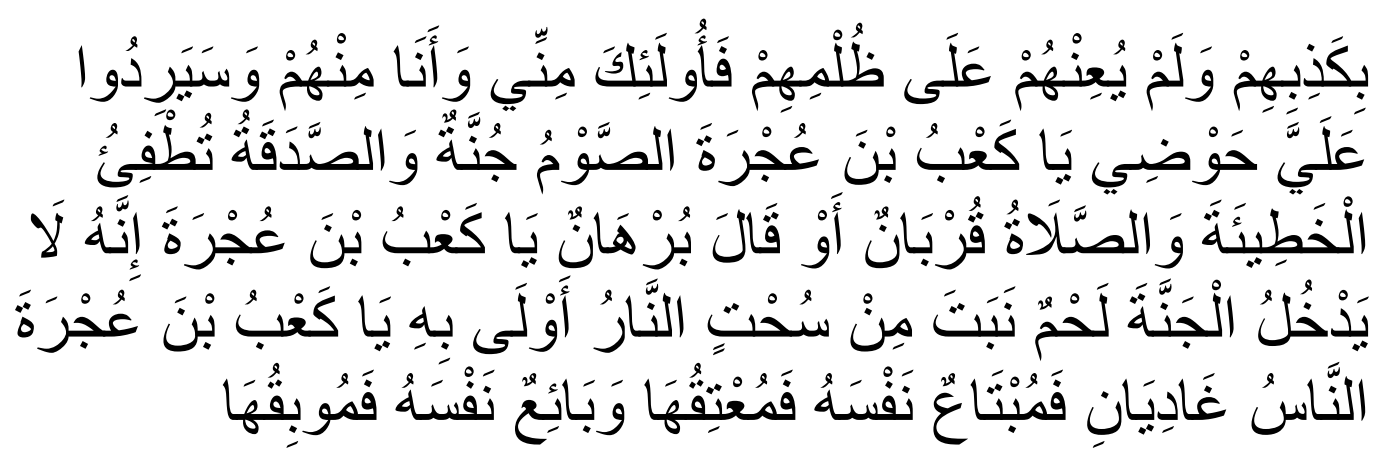

The Messenger of Allah (may peace be upon him) said to Ka'ab bin Ujrah: may Allah protect you from the foolish (ignorant) leaders. Ka'ab bin Ujzah asked: what is meant by a foolish leader, O Messenger of Allah? He replied: they are the leaders who lived after me. My guidance never guided them, and they did not follow my sunnah. Whoever justifies their lies or supports their tyranny, then that person does not belong to my group because I am not such a person. They will also not get drinking water from my well. O Ka'ab, indeed fasting is a fortress, almsgiving can remove mistakes, while prayer is an effort to get closer to God (qurban)- in another narration burhan (evidence)- $\mathrm{O} K \mathrm{Ka} a b$, indeed, will not enter heaven a pile of meat that comes from illicit goods. And the fire of hell is more entitled to devour it. O Ka'ab bin Ujrah, man is divided into two groups: first, the person who buys himself (controls himself), then he is the one who frees himself. The one who sells himself, then he is the one who destroys himself. (HR. Ahmad bin hambal)

\section{h. Must say the truth to the leader even though it feels bitter}

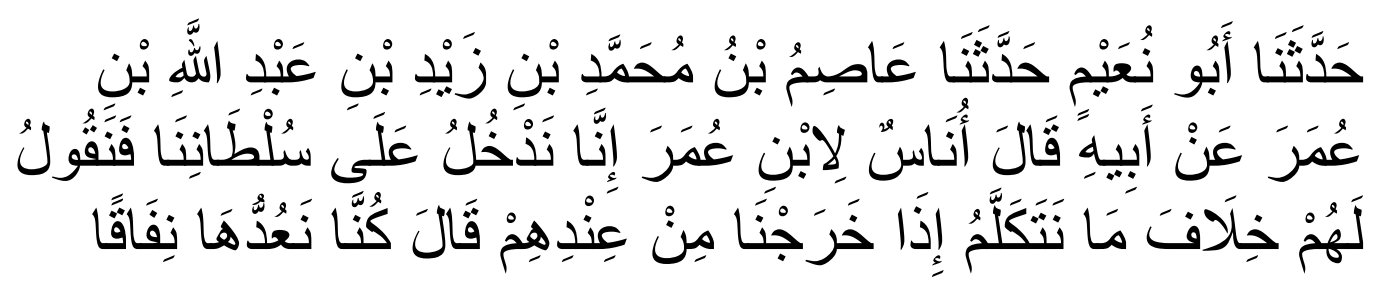

A group of people said to Ibn Umar; if we met our leaders, we would have said something completely different from what we would have said if we had not met them (leaders). Ibn Umar said: We consider that hypocrisy. (HR. Bukhari)

\section{i. Three calamities}


Three things are classified as calamities that destroy, namely (i) A ruler when you do good to him, he does not thank you, and when you make mistakes he does not forgive; (2) Neighbors, when he sees your goodness he keeps it (kept secret/silent), but when he sees your bad, he spreads it; (3) When your wife is gathered, she disturbs you (among them with hurtful words and actions), and when you leave (not in place) she will betray you. (HR. Ath-Thabrani)

\section{j. The greatest betrayal}

The greatest betrayal is when a ruler traffics his people. (HR. Ath-Thabrani)

\section{k. Jamaah}

Two people are better than one, three are better than two people, and four are better than three people. Stay in the congregation. Indeed, Allah Azza wajalla will not unite my people except in guidance (hidayah). (HR. Abu Dawud)

\section{Dakwah Politic vs Politic Dakwah}

Currently, dakwah and politics are seen as two different fields. This opinion proved detrimental because both politics and dakwah are essentially interrelated in functional, even organic matters. In Islam, humans are referred to as caliphs or leaders of the universe to realize Allah's will. Equipped with religious principles, dynamics, creativity, ratio, and trust, it is a human duty to overcome every challenge. The relationship between Islam and politics has been discussed on various occasions. The relationship between the two is often described as two sides of one coin so closely that it is impossible to separate.

Religion should be maintained and owned by its adherents as a medium to seek support and provoke the listeners who listen to it. Religion is used as an identity for people who are in politics, which can make themselves higher and elevate their status. Religion is currently widely used for personal interests in everyone. In the name of religion in politically-related activities, even many hadiths whose meaning does not contain politics are linked with politics to attract various groups to follow and be influenced. 
How the state politically provides da'wah activities and how da'wah activities support the state's lofty ideals. The verses of the Qur'an are used in such a way as to strengthen what they say in public, regardless of risk or danger; they quickly recite the verses and explain the verse with politics, which has nothing to do with it. Politics in Islam, there is no prohibition to practice or practice it. However, even in politics, we cannot be as accessible as we want or in politics without seeing certain boundaries. Religion does not justify the politicization of religion, namely politics, by tricking religious people for political purposes. Politics that should be based on the Qur'an and Sunnah (according to religious teachings) seems reversed where religion is forced to conform to political will. The human reason should be able to penetrate the sky (capture God's intention), but instead, it seems that God's "taste" is forced to submit to the limited and low human thoughts (lusts).

There are two kinds of politics in the Islamic world: high politics (high-quality politics) and low politics (low-quality politics). High politics includes several principles, for example, politics as trust, accountability, and brotherhood. Whereas low politics, which is colored by violence, brutality, cruelty, total submission, and unethical political interactions, all remind us of the Machiavellian style of politics. Islam only discusses high politics in practice for the good of society.

Victory seekers usually interpret politics as limited to the presidential, regional, and legislative elections (RI/regional). The definition of common and easily understood politics is only limited to the art of gaining and maintaining power. Because that is all there is to it, it is not necessary to expect their work programs to impact the nation's intelligence and general welfare. Because they only work to win and maintain victory. So do not be surprised if politics has a negative meaning.

Ideally, victory in the political definition should be positioned due to their efforts (candidates/supporters), not goals. In the election, the goal is to find a leader, namely who is trustworthy, fair, intelligent, and worthy or worthy to occupy a particular position. That way, it does not matter who wins. We need the democratic process to run well. From this good process, the person who deserves to win will be chosen later. Finally, the religious arguments will remain in their position, and their sanctity will be maintained as a reference in politics (political arguments), not tools for political purposes (political arguments). Dakwah awareness was born from the encouragement of revelations received by Muslims in Mecca and 
Medina in the early days of Islam. This encouragement is described in the Qur'an as وَسَطًَا أُمَّةً Q.S Al-Baqarah: 143.

If then we return to the responsibility of the people who have to carry out Islamic dakwah throughout the world, then this da'wah activity will not be carried out easily unless the people understand the politics of governance in these countries, namely the politics of the government of the ruling state (whose people they preach). Carrying out dakwah is fardlu. In this case, one will not succeed except by understanding political issues as a whole (at home and abroad), so understanding political issues is also fardlu for Muslims. As the rules of sharia state: "If an obligation is not carried out perfectly except by an act, then the act is obligatory."

When Muslims receive the responsibility of carrying out Islamic dakwah, it becomes an obligation for Muslims to always follow the world's developments with full awareness and understand the problems and various conditions. Recognize the tendencies of the state and its people, follow the political activities that taking place in the world (internationally), paying attention to the political plans of countries regarding the strategy of implementing politics and the procedures for relations between some countries and other countries, including political maneuvers that a country will carry out. They (the Muslims) must understand the political arena of the Islamic world in the constellation of the international political arena. All this is done to make it easy for Muslims to determine ways, enforce, establish, and maintain their country's existence during an international position in this world. Thus the Muslims will be able to carry out dakwah to all corners of the earth.

Dakwah, in the sense of an invitation to goodness, is an obligation. However, in realizing these obligations, everyone needs stability guarantees and state laws. The State is the integration of political power, and it is the central organization of political power. The State is a tool of the State that has the power to regulate human relations in society and publish symptoms of power in society. So it can be said that the State speaks of the structure and form of the desired society. So the teachings of da'wah to goodness, positive attitudes and behavior, leaving evil, and other negative behavior can be the color or content of society's desired structure and form. Here, the relationship between da'wah and politics or the State seems to be complementary. ${ }^{11}$

11 Taqwa, T. (2019). DAKWAH DAN NEGARA. Vox Populi, 1(1), 64 
Furthermore, dakwah must be more intelligent to capture the inclusiveness and universality of Islam. The superiority of Islamic dakwah lies in its inclusiveness that is tolerant of other religions and nations. Moreover, if the preachers understand well the character of the universality and inclusiveness of Islam, the dakwah will take place well. Furthermore, in the context of the State, if politicians and statesmen apply a climate of universality, the relationship between dakwah and politics will support each other. As Imam Ghazali said: Verily, the corruption of the people is caused by the greed of their rulers and the corruption of the rulers and the corruption of the rulers is caused by the corruption of the scholars, and the love of wealth and position causes the corruption of the scholars. Moreover, whoever is ruled by his worldly ambitions, he does not. $^{12}$

Moreover, in Indonesian conditions, the relationship between da'wah and politics can be seen in three views.

a. The accommodative group states that spiritual life is governed by religion, and secular life is governed by secular logic. Therefore, efforts are needed to separate da'wah and politics.

b. Moderate groups argue that Islam is not only understood as a religion but as an ideology. Islam is a totalistic religion (kaffah) that regulates people's lives, including socio-political life.

c. The idealist-radical group states that Islam exists in all ideologies so that to make sacrifices, complicated methods are needed and at the same time reject the five-principle ideology as the only basis as an organization for social life and that religion must be an ideology to change Pancasila.

In the perspective of the Qur'an, politics wants to be a philosophy of dakwah as a reference, has a positive goal so that it is possible to become politics as a medium of dakwah. Dakwah, through politics, is expected to be able to organize society based on akhlak al-karimah (good behavior), unite the community with an attitude of brotherhood and love. Able to uphold justice, welfare, and cooperation. They uphold leadership functions for the community's needs, managing society with fair laws and beneficial progress. Thus, understanding that dakwah in a political frame must be applied based on morality and pay attention to political ethics.

\section{Conclusion}

${ }^{12}$ Abu Hamid Al-Ghazali, Al-Mustashfa min Ilmi Al-Ushul, Riyadh: Daar Al-Mihan, tt 
The state system is more of a policy that prioritizes the welfare of the people and avoids damage on this earth. In addition to the obligation for every Muslim individual to choose a political awareness based on Islam, according to the syar'l, the Muslimin are also commanded to create a group (in this case Kutlah Siyasi) that carries out Islamic preaching and activities to revive Islamic life.

Allah SWT says:

"And let there be among you a group of people who invite to goodness and call to goodness and prevent from evil. And they are the lucky ones". (QS: Ali Iran: 104)

With this proposition, Allah SWT has required Muslims to join the political Kutlah that carries the preaching of Islam and be active in reviving Islamic life (isti'nafil hayah al Islamiyah). In this verse, Allah SWT has explained the method that Muslims should carry out the mission of Islam, namely amar ma'ruf nahi munkar. Taking the affairs of the Muslims with other than the rules revealed by Allah is apparent evil. Meanwhile, realizing the arrangement of the affairs of the Muslims with the rules revealed by Allah SWT is a greater amar ma'ruf. Therefore, it becomes an obligation for Muslims to implement the Muslims.

What else can Muslims do now other than return to political consciousness with a perspective (framework) that then seeks to create groups (ahjab siyasiyah) that carry the message of Islam and are active to revive Islamic life? Similarly, if the Muslims want to return to the true meaning of politics.

Furthermore, people who love to talk politics generally infer something from news sources with no origin and facts. But it is just waham (imagination) that their minds build opinions and talk about it. It means they follow something without knowledge. Allah Ta'ala says:

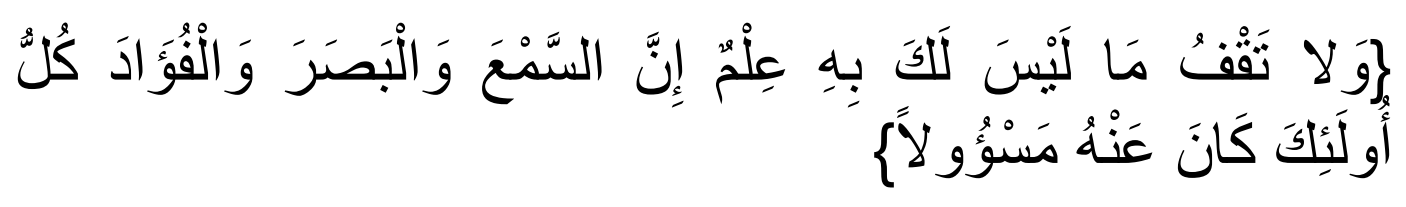

"And do not follow that of which you have no knowledge. Indeed, hearing, sight and heart, all of them will be held accountable." (Al Isra: 36).

Politics is a crucial thing for a Muslim, and it is wrong if someone thinks that Islam does not have to be political justice for the entire Indonesian nation. 


\section{REFERENCES}

Al-Quran and Translation

Atabik Ali dan Zuhdi Muhdlor, Kamus Kontemporer, Kamus Munjid.

AYAT-AYAT DAKWAH DALAM AL-QUR'AN. Al-Idarah: Jurnal Manajemen Dan Administrasi Islam, 1(2), 167.

Day, S. B. (2005). Hubungan Politik dan Dakwah. Mediator: Jurnal Komunikasi, 6(1), 7-16. https://doi.org/10.29313/mediator.v6i1.1171

Khairan Muhammad Arif, Moderasi Islam Telaah Komprehensif Wasathiyah Islam dalam Perspektif Al-Qur'an dan As-Sunnah ,enuju Islam Rahmatan Lil Alamiin, Jakarta: Pustaka Ikadi, 2020 $12: 07$

https://id.wikipedia.org/wiki/Politik accessed in 16 October 2020 at

https://www.hadits.id/tentang/pemimpin accessed in 17 October 2020 at 11:07

https://tafsirzilal.wordpress.com/2012/06/05/bahasa-indonesia-2/ accessed in 16 October 2020 at 11:07

Abu Hamid Al-Ghazali, Al-Mustashfa min Ilmi Al-Ushul, Riyadh: Daar Al-Mihan, $\mathrm{tt}$

Katimin, Katimin and Is, Fadhilah and Faza, Asrar Mabrur (2018) Hadis-Hadis Politik: Prof Katimin. Perdana Publishing, Medan.

Munawwir, A. W., Kamus Al-Munawwir Arab-Indonesia, 1997. Surabaya: Pustaka Progressif,

M. Munir dan Wahyu Ilahi dalam A. M Ismatullah. Metode Dakwah Dalam Al-Qur'an: Studi Penafsiran Hamka terhadap QS. An-Nahl: 125. Lentera, Vol. IXX, No. 2 , Desember 2015

Surbakti, R. 1992. Memahami Ilmu Politik. Jakarta: PT Grasindo

Taqwa, T. (2019). Dakwah Dan Negara, Vox Populi, 1(1), 64. https://doi.org/10.24252/vp.v1i1.8095

Taymiyyah, Ibnu. al Siyasah al Syar'iyyah fi Ishlah al Ra'ie wal Ra'iyyah.

Yusuf, M., Zain, A., \& Fuadi, M. (2017). IDENTIFIKASI 
Al-Risalah: Jurnal Studi Agama Dan Pemikiran Islam | Vol. | No. | 2021

Badrah Uyuni | Relationship Between Politics And Dakwah In The Qur'an And As-Sunnah 